Eskişehir Osmangazi Üniversitesi iißBF Dergisi

Ağustos 2019, C. 14, S. 2, 331 - 346.

Başvuru : 06.08.2018

Kabul : 26.07.2019

\title{
Kaldıraç ve Döngüsellik: Bankacılık Sektörü Üzerine Bir Uygulama
}

\begin{abstract}
Kaldıraç ve Döngüsellik: Bankacılık Sektörü Üzerine Bir Uygulama

Öz

Bu çalışmanın amacı, 2006 Ocak-2018 Ocak döneminde bankacılık sektöründe faaliyet gösteren bankaların kaldıraç yapısının döngüselliğini araştırmaktır. Döngüselliğin tespiti için, kaldıraç oranı ve aktif değişimi arasındaki ilişki regresyon analizi ile incelenmiştir. Regresyon analizi tahminleri, aktif değişiminin kaldıraç oranı değişimini pozitif yönlü ve istatistiki olarak anlamlı bir şekilde etkilediğine işaret etmektedir. Bu sonuç, kaldıracın döngüsel olduğunu göstermektedir. Kaldıracın döngüselliği, banka varlıklarının büyüme gösterdiği dönemlerde, kaldıraç oranının artmasına ve finansal çevrimler ile kredi çevrimlerinin birbirini tetiklemesine sebep olabilmektedir. Bu şekilde, kaldıracın finansal hızlandırma mekanizma olmasından yola çıkılarak, finansal genişleme dönemlerinde döngüsel karşıtı bir politika belirlenmesi ile makro riskleri azaltabilen önlemler geliştirilebileceği söylenebilir.
\end{abstract}

Anahtar Kelimeler: Kaldıraç Döngüselliği, Finansal Çevrimler, Kredi Çevrimleri, Finansal Hızlandırıcı Mekanizma.

\author{
Leverage and Procyclicality: An Application on Banking \\ Sector
}

Abstract

The purpose of this study is to investigate the procyclicality of the leverage structure of the banks operated in banking sector in the term of 2006 January-2018 January. In order to determine the procyclicality, the relationship between the changes of leverage rate and asset was investigated by regression analysis. The estimations of the regression analysis indicate that the asset change affects the leverage rate change positive direction and statistically significant. This result shows that the leverage is procyclical. Leverage procylicality can cause increase in the leverage rate and trigger of the financial cycles and the credit cycles each other during periods when the banks assets grow. In this way, it can be said that by taking approach the leverage as a financial accelerator mechanism, with determined countercyclical policy during financial expansion periods, the precautions can be developed that can decrease macro risks.

Keywords: Leverage Procyclicality, Financial Cycles, Credit Cycles, Financial Accelerator Mechanism.

\section{Giriş}

Bankalar, ulusal ekonomideki işlevlerinden ve finansal sistemin en önemli aracı kurumları olmalarından dolayı stratejik bir fonksiyona sahiptirler. 2007 mali krizine kadar, bankacılık sektöründe, finansal piyasaların işleyişinde her bir bankanın ödeme gücü konusunda önlem alabildiği, finansal sistemin istikrarını sağlamanın mümkün olabildiği savı hakim olmuştur. Ancak, sistematik riskler bu şekilde göz ardı edilmiştir. Belirli riskler finansal piyasada sadece katılımcıları bireysel olarak etkilerken; sistematik riskler, bir bütün olarak finansal sistemin işleyişini etkilemektedir (Avcı ve Çatak, 2016: 42).

2007-2009 küresel krizi, finansal sektörde başlamış ve hızla üretim, istihdam ve ticaret alanında daha önce görülmemiş bir düşüşle küresel bir durgunluğa dönüşmüştür. 2007-2009 küresel krizinden önce, piyasada yaşanan krizler, bankaların ve firmaların finansman koşullarının finansal krizleri resesyonlara dönüştüren kilit mekanizmalar olduğunu göstermektedir. Dış finansman ve azalan teminat değerlerinin yüksek maliyeti, daha düşük verime yol açan yatırımları azaltarak, firmaların kaldıraç oranını düşürmeye zorlamaktadır. İş çevrimi üzerindeki kaldıraç

${ }^{1}$ Arş. Gör. Dr., Ağrı İbrahim Çeçen Üniversitesi, iiBB, İşletme Bölümü, ekaya@agri.edu.tr. Yazar ORCID bilgisi: http://orcid.org/0000-0002-7035-9241.

2Öğr. Gör., Ağrı İbrahim Çeçen Üniversitesi, Turizm İşletmeciliği ve Otelcilik Yüksekokulu, Konaklama İşletmeciliği Bölümü, ykoksal@agri.edu.tr. Yazar ORCID bilgisi: http://orcid.org/0000-0001-7781-8220. 
değişiklikleri, reel ekonomiye ilk ters şoku yayan önemli bir mekanizmadır. Birçok yorumcu, 2000 'li yılların başlarındaki alt krizleri körükleyen borç verme patlamasının, firmaların ve bankaların kaldıraçlarını daha önce görülmemiş seviyelere çıkarmasına neden olduğunu ileri sürmüşlerdir (Kalemli-Özcan vd., 2011: 1).

Geçmiş yıllarda yaşanan ekonomik ve finansal krizler, finans ve bankacilık sektörünün aslında döngüsel olduğunu göstermiştir. Bankacılık sektörünün döngüsel davranışı, literatürde hem teorik hem de deneysel açıdan incelenmektedir. Keynes (1936) ve Minsky (1982), asimetrik bilginin finansal piyasaların işleyişinde doğal bir sorun olduğunu ve bu belirsizliğin reel ekonomiyle dalgalandığını iddia etmektedirler. Bernanke ve Gertler (1989) ve Kiyotaki ve Moore (1997), finansal hızlandırıcıyı; ekonomideki daha küçük şokların iş çevrimlerinin artmasına neden olması ve kredi piyasalarının durumunun içsel değişkenlerle daha da güçlendirilebilmesi şeklinde ifade etmişlerdir. Genel olarak, iktisat politikası, ekonomik ve finansal çevrenin ve bankaların düzenleyici faktörleridir ki bu faktörler de bankacılık sektörünün döngüselliğinin sürekliliğine katkıda bulunmaktadır (Athanasoglou, 2013: 2).

Basel Bankacılık Denetim Komitesi, bankalar arasındaki haksız rekabeti önlemek, banka sistemlerindeki piyasa risklerini ve kredi risklerini azaltmak adına, bankaların sermaye yeterlilik oranının denetlenmesi için Basel I'i geliştirmiştir. Komite tarafından Basel I, 2003'te tekrar gözden geçirilerek en az sermaye yeterlilik şartıyla Basel II olarak yeniden düzenlenmiştir. Ne yazık ki, Basel II olarak getirilen düzenleme 2008'de Amerika'da meydana gelen mali krizi durduramamıştır. Kriz öncesinde, dünyanın çeşitli ülkelerindeki büyük bankalar Basel II'nin sermaye yeterlilik oranının \%8'den az olması şartını memnuniyetle uygulamışlardır. Ayrıca, bu bankaların kaldıraç oranları da daha düşük düzeyde tutulmuştur. Kriz sonrasında, banka varlıklarının ölçeği büyük ölçüde küçülmüştür. Kaldıracın hızla düşmesi piyasa likiditesinin azalmasına ve kredi sıkışıklığına sebep olmuştur ve böylece kriz daha da derinleşmiştir. Bilançonun arkasında finansal türevler veya varlık menkul kıymetleştirmesi gibi karmaşık risklerin olduğu açıktır ki, sadece sermaye yeterlilik oranı kullanılarak etkin bir şekilde denetlemenin yapılamayacağı tespit edilmiştir. Bu nedenle, finansal sistemin istikrarı için yeniden düzenlemeye gidilmiştir ve 2010 'da G20 Zirvesi tarafından Basel III'ün kaldıraç oranı minimum \%3 olarak uygun görülmüştür (Wu ve $\mathrm{Hu}$, 2017: 137).

İktisadi döngünün güçlenmesinde kaldıraç döngüsü önemli bir rol oynamaktadır. Kaldıraç oranı genellikle döngüsel bir davranış sergileyebilmektedir. Çünkü, kriz dönemlerinde sermaye tedarik etmek zor olduğundan; bu durumda bankalar ya varlıklarını satmaya ya da öz varlık artışına gitmektedirler. Bankalar, bu gibi durumların çoğunda varlıklarını satma yolunu ve menkul kıymetlerin fiyatlarını daha da düşürmeyi tercih etmektedirler. Kaldıraç oranı sabitleninceye kadar fiyatlardaki bu düşme ve varlıkların satışı, devam etmektedir.

Kaldıraç oranları, ekonominin durgun olduğu dönemlerde düşmekte; ekonominin yükseldiği dönemlerde ise artmaktadır (Avcı ve Çatak, 2016: 42). Öyle ki, bankalar, aktif büyüklüklerinin arttığı dönemlerde, düşen kaldıraç oranlarını yükseltmek için, daha fazla kaynak bulma arayışı içerisine girmektedirler. Finans literatüründe bu durum "Kaldıracın Döngüselliği" olarak tanımlanmaktadır (Terzioğlu ve Demir, 2015: 547). Döngüsellik, bir ekonominin reel ve finansal sektörlerinin doğal bir parçasıdır. Birçok ekonomist tarafından da bankaların davranışlarının döngüsel olduğu kabul edilmekte ve bu döngüselliğin de makroekonomik ve finansal istikrarı tehdit edebileceğine inanılmaktadır. Ekonomistler, her bir finansal krizin arkasında makroekonomik faktörlerin olduğunu düşünmektedirler. Çünkü, finansal kurumlar da faaliyetlerini değişen makro ekonomik koşullara bağlı olarak sürdürmektedirler (Avcı ve Çatak, 2016: 43). 
Bankacılık sisteminin hızlı büyüdüğü ve kaldıraç oranının arttığı dönemler, kredi çevrimlerinin güçlendiği dönemlerle veya kredi çevrimlerinin genişleme evresiyle örtüşebilmektedir. Kaldıraç oranlarının böyle döngüsel olması ise, kaldıraç döngüselliğinin finansal çevrimleri hızlandıran bir işlev gördüğüne işaret etmektedir. Bu durum, kaldıraç oranlarının, makro finansal riskleri azaltıcı bir araç olarak kullanılmasına olanak sağlamakta ve kaldıracın kredi çevrimlerini yumuşatmayı sağlayabilecek bir işlev görebilmesini de mümkün kılabilmektedir (Binici ve Köksal, 2012: 2). Bu sebepten ötürü, bankalar için kaldıraç mekanizması önem arz etmektedir.

Kalemli-Özcan vd. (2011), kaldıraç mekanizmasının niçin önemli olduğunu Adrian ve Shin'in $(2008,2010)$ çalışmalarında "The Adrian-Shin Model" diye adlandırdıkları modelden yola çıkarak açıklamışlardır. Modeldeki ilk döngüde, varlık değerleri artınca, kaldıraç oranlarının düşmesi durumunda bankaların kaldıraç hedeflerine ulaşabilmeleri için daha fazla kaynak bulmaya çalıştıklarını ve böylelikle bankaların bilanço büyüklüklerinin arttığını dolayısıyla bu durumun da kaldıraç oranının döngüselliğini kanıtladığını ifade etmişlerdir. Yazarlar, bankalardaki büyüme eğiliminin ise, kaldıraç oranlarında artışa sebep olduğunu belirtmişlerdir. Modelin diğer döngüsünde; bankaların varlık değerlerindeki azalmayla, yükselen kaldıraç oranlarını düşürme eğilimine gittikleri ve netice olarak bilanço büyüklüklerini düşürmeye başladıkları belirtilmiştir. Literatürde, bu durum döngüselliğin karşıtlığı olarak tanımlanmıştır.

Bu çalışmada, Türkiye'de Ocak 2006-Ocak 2018 dönemi için faaliyet gösteren mevduat, katılım ve kalkınma bankalarının kaldıraç yapısının döngüsel olup olmadığının belirlenmesi hedeflenmektedir. Ulaşılacak bulguların, bankacılık seköründe kaldıraç döngüselliğinin tespiti ile, döngüsellikten kaynaklanan aktif şişkinliğinin olması durumunda, döngüsel karşıtı bir politika önermesinin yapılıp yapılmayacağı konusunda ışık tutması beklenmektedir. Kaldıraç döngüselliği, araştırmaya dahil edilen bankaların aktif ve kaldıraç oranı değişimleri kullanılarak, regresyon analizi ile araştırılmıştır. Regresyon analizi bulguları, kaldıraç oranlarının döngüsel olduğuna işaret etmiştir. Bu durum ise, kaldıracın finansal hızlandırıcı bir mekanizma olduğunu ve finansal çevrimlerle kredi çevrimlerinin birbirini desteklediğini göstermektedir. Çalışmanın literatüre katkıları ise, döngüselliğin tespitinin yanı sıra, bankacılık sektörünün döngüsel davranış sergileyip sergilemediğinin araştırılmasında yaygın olarak kullanılan kaldıraç oranları olan borç/özkaynaklar ve aktif/özkaynaklar'a ek olarak alternatif kaldıraç oranlarının kullanılması, araştırmanın hem sektör hem de banka grupları için ayrı ayrı yapılarak döngüsel davranışın sektör ve sektörde faaliyet gösteren bankalar için ayrı ayrı gözlemlenmesidir.

Çalışma beş bölümden oluşmaktadır. Takip eden bölümde, kaldıraç döngüselliğinin araştırıldığı çalışmalara ilişkin kısa bir literatür özetine değinilmekteyken, üçüncü bölümde, araştırmada kullanılan veri seti ve yöntem tanıtılmaktadır. Dördüncü bölümde, Türk bankacılık sektöründe faaliyet gösteren bankaların kaldıraç yapısının döngüsel olup olmadığına ilişkin kanıtlar sunan analizlere ait bulgulara yer verilmektedir. Son bölümde, sonuç ve önerilere değinilerek çalışma tamamlanmaktadır.

\section{Literatür}

Literatürde kaldıraç oranının döngüselliği konusundaki yapılan çalışmalar sınırlı olsa da kaldıraç döngüselliği farklı yaklaşım ve metotlarla analiz edilmeye çalışıımıştır. Bu alanda Adrian ve Shin'in 2008'de ve 2010'da yaptıkları çalışmalar diğer çalışmalara ışık tutması açısından önem arz etmektedir. Adrian ve Shin $(2008,2010)$, çalışmalarında 1997-2008 yılları arasında ABD faaliyet gösteren ve piyasa değeri en büyük beş yatırım bankası için kaldıracın kuvvetli bir şekilde döngüsel olduğunu kanıtlamışlardır. Her bir grup finansal kuruluşun piyasadan piyasaya devamlı olarak ideal bir bilanço büyüklüğünü sürdürmeleri için tahmini bir yaklaşımda bulunmuşlardır. 
Bu nedenle, bilanço büyüklüğüyle finansal kuruluşların kaldıraç oranları arasındaki ilişkiyi kanıtlamayı hedeflemişlerdir. Bankaların kendi varlık değerlerini arttırdıklarında, bilanço boyutlarını da arttırdıklarını ve daha fazla yabancı kaynak edinerek daha fazla borç verme yoluna gittiklerini tespit etmişlerdir. Yine çalışmalarında riske maruz değer (VaR) modelini kullanarak, bu bankaların finansal gelişme döneminde düşük riskten dolayı, kaldıraç oranlarını yüksek tuttuklarını açıklamışlardır.

Gropp ve Heider (2010), 1991'den 2004'e kadar Avrupa Birliği'ne (AB) üye 15 ülke ve ABD olmak üzere toplam 16 ülkede faaliyet gösteren ticari bankaların ve finansal kuruluşların faaliyet yapılarını dikkate alarak kaldıraç davranışlarını incelemişlerdir. Gropp ve Heider (2010), gözlemleri sonucunda, bankaların kaldıraç davranışlarının zaman içinde değişmediğini, kendine özgü bir yapıda olduklarını tespit etmişlerdir. Damar vd. (2010), Kanada bankacılık sektöründe aktiflerin büyümesiyle kaldıraç oranları arasında bir ilişki olup olmadığını sorgulamışlardır. 1994-2009 yılları arasında Kanada'da faaliyet gösteren 136 banka için çalışma gerçekleştirilmiştir. Yazarlar, kaldıraç oranı olarak Toplam Aktif+Bilanço Dışı Varlıklar/Özkaynaklar oranını kullanmışlardır. Araştırma bulguları, aktif büyümesiyle kaldıraç oranı arasında pozitif güçlü bir ilişkinin olduğunu göstermiştir.

Kalemli-Özcan vd. (2011), ABD’de faaliyet gösteren büyük ticari bankalar için kaldıracın döngüsel olduğunu; buna nazaran Avrupa ülkelerinde faaliyet gösteren bankaların döngüselliğin daha az olduğu sonucuna varmışlardır. Çalışkan (2011), Türk bankacılık sisteminin kriz sonrasında nasıl sıfır veya az zararla çıktığına dair durum analizi yaptığı çalışmasında, Türk bankacılık sistemiyle ABD bankacılık sistemini karşılaştırmıştır. 1994-2009 dönemini kapsayan, yıllık ve çeyreklik veriler kullanılarak yapılan panel regresyon analizi sonucunda yazar, Türk bankalarının bilançolarının genişledikçe, kaldıraç oranlarının arttığını; tersi durumunda ise, kaldıraç oranlarının azaldığını; dolayısıyla, Türk bankalarının konjonktür yönlü kaldıraç davranışı sergilediğini belirtmiştir. Ayrıca, 2001 krizi sonrası Türk bankacılık sisteminde faaliyet gösteren bankaların toplam kaldıraç oranının ABD bankacılık sisteminde faaliyet gösteren bankalardan daha düşük olduğu belirlenmiş ve Türk bankalarının kaldıraç döngüselliği davranışı sergilediği tespit edilmiştir. Öte yandan, konjonktür yönlü olan kaldıraç davranışının finansal sistemi istikrarsızlaştırması beklenmesine rağmen; Türk bankacılık sektöründe faaliyet gösteren bankaların kaldıraç büyüme hızı katsayısının ABD bankacılık sektöründe faaliyet gösteren bankalara göre düşük olduğu ifade edilmiştir. 2001 krizi sonrası Çalışkan'a göre, bankacılıkta getirilen sıkı düzenleme ve denetlemeler kaldıraç büyüme hızını anlamlı bir şekilde azaltmıştır ve ABD'de ise, kriz sonrası dönemde tam tersi olarak finansal serbestleşme eğilimi görülmüştür.

Binici ve Köksal (2012), çalışmalarında Türk bankacılık sisteminde 2002-2011 dönemi için kaldıraç yapısının döngüselliğini ele almışlardır. Çalışma kapsamında kaldıraçla aktif büyüklüğü arasındaki ilişkiye bakılmıştır ve bu iki değişken arasında pozitif ve anlamlı bir ilişki tespit edilmiştir. Buna bağlı olarak ise; bankacılık sistemi büyüme gösterdiğinde, kaldıraç oranının da arttığı ve kaldıracın döngüsel olduğu sonucuna varılmıştır. Çalışma kapsamında, işlev bakımından banka grupları arasında da farklılıklar bulunmuştur. Daralma dönemlerinde de kaldıraç oranının düştüğü tespit edilmiştir. Kaldıracın döngüsel olmasını ise Binici ve Köksal (2012), hem banka bilançolarının genişleme ve daralmalarının kredi çevrimlerini hızlandırmakta olduğunu, hem de kaldıraç ve iş çevrimleri ilişkisini ortaya koyduğunu ifade etmişlerdir. Bu durumun bir sonucu olarak, kaldıraç oranının da dikkate alınmasının döngüsellik karşıtı makro riskleri azaltıcı önlemlerde geliştirilecek olan politikalarda da faydalı olacağı önerilmiştir. 
Baglioni vd. (2013), Adrian ve Shin'in çalışmasını baz alarak geliştirdikleri çalışmalarında, 2000 ve 2009 yılları arasında 77 büyük Avrupa bankası üzerindeki kaldıraç oranı döngüselliğinin etkilerini araştırmışlardır. Araştırma bulguları, kaldıraç döngüselliğinin yatırım ve ticari bankalar için yerleşmiş bir davranış şekli olduğunu ve döngüselliğin finansal genişleme ve kriz dönemlerinde arz yönlü bir finansal hızlandırıcı mekanizma olduğunu göstermiştir. Terzioğlu ve Demir (2015), 2002 ve 2014 yılları arasında Türk bankacılık sisteminde faaliyetini sürdüren ilk on mevduat bankasının aktif değişimleri ile kaldıraç oranlarının değişimi arasındaki bağıntıyı En Küçük Kareler (EKK) yöntemi ile çeyreklik dönemler itibariyle test etmişlerdir. Çalışmada, kaldıraç oranları olarak literatürde sıkça kullanılan aktif/özkaynak ve borç/özkaynak oranları dikkate alınmıştır. Türk banklarının kaldıraç oranlarının döngüselliğinin diğer bir ifadeyle ekonominin genişlediği dönemlerde kaldıraç oranlarının artıp artmadığının araştırıldığı çalışmada bulgular doğrultusunda, Türk bankacılık sektörünün kaldıraç oranlarının döngüsel olduğu ve kaldıraç döngüselliğinin Türkiye için bir piyasa kontrol mekanizması olarak kullanılabileceği sonucuna varılmıştır.

Laux ve Rauter (2015), çalışmalarında yönetimden, raporlamadan kaynaklanabilecek olası problemlerin tanınması için kaldıraç döngüselliğinin belirleyicilerinin anlaşılmasının çok önemli olduğunu vurgulamışlardır. Yazarlar, ABD bankacılık sektöründe faaliyet gösteren ticari ve tasarruf bankaları için kaldıraç döngüselliğinin belirleyicilerine odaklanmışlar ve bankaların, yasal risk ağırlıklarıyla bankalar arasındaki ortalama risk ağırlıklarındaki değişimler arasındaki farkı sorumlu tutmak ve toplam varlıklarını döngüselliğe neden olmak için kaldıraç oranlarını artırdığını tespit etmişlerdir. Laux ve Rauter (2015), çeşitli ekonomik ve bankaya özgü değişkenlerin kontrol edilmesine rağmen, bankaların kaldıraç oranlarının, sadece gerçeğe uygun değer muhasebesi nedeniyle değil, aynı zamanda bilançonun düzenlenmesiyle güçlü bir şekilde döngüsel olduğunu keşfetmişlerdir. Döngüselliğin temel itici güçleri olan belirleyicilerden bazılarının gayri safi yurt içi hasıla (GSYiH) büyümesi, kredi satışları ve ortalama risk ağırlıklarının artışı olduğu yine çalışmada belirtilmiştir.

Bruno ve Shin (2015), kaldıracın finansal riskler üzerinde en büyük etkiye sahip faktör olduğunu ve kaldıraç katsayısının arttıkça risklerin de arttığını öne sürmüşlerdir. Bu anlamda AmelZadeh, Barth ve Landsman (2015), yine bankaların kaldıraç döngüselliği davranışlarının nedenlerini risk ağırlıklarına dayanarak düzenlemeleri gerektiği sonucuna varmışlardır. Kyounghoon (2016), çalışmasında ABD bankacılık sektöründe yer alan ticari ve uluslararası faaliyet gösteren bankaların kaldıraç döngüselliklerindeki heterojenliğin belirleyicilerini araştırmak amacıyla, bulunulan dönemde ve farklı dönemlerde karşılaştırmalı olarak ampirik kanıtlarını sunmuştur. Bulgular, farklı iş modellerine dayanan heterojen döngüselliğe yönelik tedbirlerin geliştirilmesinin gerekliliğine ve iş çevrimi dinamiklerinin incelenmesi için makro modeldeki belli olguların yerleşmesine ışık tutmaktadır.

Avcı ve Çatak (2016), çalışmalarında banka sermaye yapısının belirleyicileriyle kaldıraç oranının döngüsel davranışını incelemişlerdir. Farklı türdeki kaldıraç oranlarıyla bankaların aktif büyüklüğü arasında ilişki olup olmadığını geliştirdikleri panel veri analiziyle test etmişlerdir. Analiz sonucunda, bankaların aktif büyüklüğü ve kaldıraç oranı arasında pozitif ilişkinin olduğu ve Türk bankalarının kaldıraçlarının döngüsel olduğu sonucuna varmışlardır. Türk bankalarının sermaye yapısına olası etki eden faktörlerin büyüklük, kar, banka sayısı, enflasyon, döviz kuru ve GSYiH olduğunu belirtmişlerdir. 


\section{Veri Seti ve Yöntem}

Bu çalışmanın amacı, Türk bankacılık sektöründe faaliyet gösteren mevduat, katılım, kalkınma ve yatırım bankalarının kaldıraç yapısının döngüselliğini incelemektir. Bu bağlamda, kaldıraç döngüselliğini etkileyen diğer faktörlerin sabit olduğu varsayımı altında, kaldıraç oranı ve aktif değişimleri arasındaki ilişkinin yönü tespit edilmeye çalışıımaktadır. Kaldıraç oranı ve aktif değişimleri arasındaki ilişkinin tespitinde, 2006 Ocak-2018 Ocak zaman aralığında aylık frekansta veriler kullanılmıştır.

Bankacılık sektörü için literatürde çeşitli kaldıraç tanımlarına rastlanmakla birlikte, aktif/özkaynak ve borç/özkaynak oranları yaygınlıkla kullanılmaktadır (Terzioğlu ve Demir, 2015: 551). Ana sermaye-sermayeden indirilen değerler/aktif+bilanço dışı yükümlülük gibi kaldıraç oranları, politika düzenleyici kuruluşlar tarafından bankacılık sektöründe risk göstergesi veya makro riskleri azaltıcı politika göstergesi olarak kullanılabilmektedir. Nitekim, bu çalışmada, bankacılık sektörü için, hangi kaldıraç oranının kullanılmasının daha uygun olabileceği tartışmasına girmeden, Binici ve Köksal (2012) takip edilerek, alternatif kaldıraç oranları kullanılmış ve kaldıraç döngüselliği araştırılmıştır. Tablo 1'de bankacılık sektörü için çalışmaya konu olan alternatif kaldıraç oranlarına yer verilmiştir. 4. Kaldıraç ve 5 . Kaldıraç oranlarının artması, borçluluğun azalması; 1. Kaldıraç, 2. Kaldıraç, 3. Kaldıraç ve 6 . Kaldıraç oranlarının artması, borçluluğun artması anlamına gelmektedir.

Tablo 1: Kaldıraç Tanımları

\begin{tabular}{lc}
\hline 1. Kaldıraç Oranı & Borç/Özkaynak \\
2. Kaldıraç Oranı & Aktif/Özkaynak \\
3. Kaldıraç Oranı & Borç+Bilanço Dışı Yükümlülük/Özkaynak \\
4. Kaldıraç Oranı & Ana Sermaye-Sermayeden İndirilen Değerler/Borç +Bilanço Dışı Yükümlülük \\
5. Kaldıraç Oranı & Ana Sermaye-Sermayeden İndirilen Değerler/Aktif+Bilanço Dışı Yükümlülük \\
6. Kaldıraç Oranı & Aktifler+Gayrinakdi Krediler+Taahhütler ${ }^{4} /$ Yasal Özkaynak \\
\hline
\end{tabular}

Çalışma kapsamına alınan değişkenler ise, Tablo 2'de sıralanmıştır.

Tablo 2: Çalışmada Kullanılan Değişkenler

$\begin{array}{ll}\text { 1. KOD } & \text { 1. Kaldıraç Oranı Değişimi } \\ \text { 2. KOD } & \text { 2. Kaldıraç Oranı Değişimi } \\ \text { 3. KOD } & \text { 3. Kaldıraç Oranı Değişimi } \\ \text { 4. KOD } & \text { 4. Kaldıraç Oranı Değişimi } \\ \text { 5. KOD } & \text { 5. Kaldıraç Oranı Değişimi } \\ \text { 6. KOD } & \text { 6. Kaldıraç Oranı Değişimi } \\ \text { AD } & \text { Aktif Değişimi }\end{array}$

Çalışmada kullanılan bankacılık sektörü ve grup banka verileri, \%'lik değişimleri ile analizlere dahil edilmiş ve Bankacılık Düzenleme ve Denetleme Kurulu'nun (BDDK) hazırladığı İnteraktif Aylık Bülten'lerden temin edilmiştir. İnteraktif Aylık Bülten'ler, bankaların yurt içi şube verilerinin yanı sıra yurt dışı şubelerinin verilerini de içermektedir. Çalışmada bankacılık sektörü ve banka grupları için ayrı ayrı, En Küçük Kareler (EKK) yöntemi kullanılarak regresyon analizleri gerçekleştirilmiştir. Sektör ve banka grupları için, kaldıraç yapısının döngüselliğinin araştırılmasında kullanılan regresyon eşitlikleri aşağıda yer almaktadır:

\footnotetext{
${ }^{3}$ 4. Kaldıraç ve 5 . Kaldıraç oranları hesaplanırken, gayrinakdi kredi ve yükümlülüklerin bütününe bilanço dışı işlemler içinde yer verilmiş, cayilabilir taahhütlerin sadece \%10'u dikkate alınmıştır (Binici ve Köksal, 2012: 16).

${ }^{4}$ Taahhütler, türev araçları ve cayılabilir taahhütleri kapsamamaktadır.
} 
1. $\mathrm{KOD}_{i, t}=\alpha_{0+} \alpha_{1} \mathrm{AD}_{i, t}+\varepsilon_{\mathrm{i}, \mathrm{t}}$

2. $\mathrm{KOD}_{i, t}=\alpha_{0+} \alpha_{1} \mathrm{AD}_{i, t}+\varepsilon_{i, t}$

3. $\mathrm{KOD}_{i, t}=\alpha_{0+} \alpha_{1} \mathrm{AD}_{i, t}+\varepsilon_{\mathrm{i}, \mathrm{t}}$

4. $\mathrm{KOD}_{i, t}=\alpha_{0+} \alpha_{1} \mathrm{AD}_{i, t}+\varepsilon_{i, t}$

5. $\mathrm{KOD}_{i, t}=\alpha_{0+} \alpha_{1} \mathrm{AD}_{i, t}+\varepsilon_{\mathrm{i}, \mathrm{t}}$

6. $\mathrm{KOD}_{i, t}=\alpha_{0+} \alpha_{1} \mathrm{AD}_{i, t}+\varepsilon_{\mathrm{i}, \mathrm{t}}$

\section{Bulgular}

Bu çalışmada bankacılık sektöründe kaldıraç döngüselliğini araştırma kapsamında, öncelikle bankacılık verilerinin özet istatistiklerine ve bankacılık sektörünün kaldıraç oranı seyirlerine yer verilmiştir. Ardından, sektör ve banka gruplarına ilişkin zaman serilerinin durağanlık özellikleri incelenerek, zaman serilerinin durağanlık seviyeleri belirlenmiştir. Değişkenlerin durağanlık özelliklerinin belirlenmesinden sonra, değişkenler arasındaki ikili ilişkilerin tespit edilmesini sağlayan EKK tahminleri raporlanmıştır. Bankacılık sektörü ve banka grupları için kaldıraç oranları özet istatistikleri ise, Tablo 3'te yer almaktadır.

Tablo 3: Bankacılık Sektörü ve Banka Grupları Için Özet İstatistikler

\begin{tabular}{ccccccccc}
\hline & \multicolumn{2}{c}{ Sektör } & \multicolumn{2}{c}{$\begin{array}{c}\text { Mevduat } \\
\text { Bankaları }\end{array}$} & \multicolumn{2}{c}{$\begin{array}{c}\text { Katılım } \\
\text { Bankaları }\end{array}$} & \multicolumn{2}{c}{$\begin{array}{c}\text { Kalkınma ve } \\
\text { Yatırım Bankaları }\end{array}$} \\
\hline Kaldıraç Oranı & Ort. & S. Sapma & Ort. & S. Sapma & Ort. & S. Sapma & Ort. & S. Sapma \\
\hline 1 & 7,22 & 0,81 & 7,79 & 0,8 & 8,33 & 1,57 & 2,16 & 1,19 \\
2 & 8,22 & 0,8 & 8,79 & 0,79 & 9,33 & 1,56 & 3,16 & 1,19 \\
3 & 15,15 & 3,04 & 16,42 & 3,11 & 16,14 & 1,88 & 4,42 & 2,29 \\
4 & 6,35 & 0,98 & 5,79 & 0,8 & 5,97 & 0,61 & 28,02 & 12,04 \\
5 & 5,94 & 0,84 & 5,45 & 0,69 & 5,61 & 0,54 & 21,14 & 7,39 \\
6 & 4,3 & 2,09 & 4,41 & 2,48 & 8,66 & 6,54 & 2,07 & 0,59 \\
\hline
\end{tabular}

*Ort.: Ortalama; S. Sapma: Standart Sapma.

Tablo 3'te yer alan kaldıraç oranları özet istatistiklerine göre, banka grupları karşılaştırıldığında, mevduat ve katılım bankalarının yüksek kaldıraç oranları ile çalıştığı; nitekim, kalkınma ve yatırım bankalarının, düşük kaldıraç oranı ile çalıştığı görülmektedir. Kaldıracın önemli belirleyicisi olan aktif büyüklüğü dikkate alındığında, mevduat bankalarının yüksek, kalkınma ve yatırım bankaların düşük kaldıraç oranı ile faaliyet göstermesi, Çalışkan'ın (2011), çalışmasında belirttiği gibi beklenen bir sonuçtur. Şekil 1'de sektör için kaldıraç oranlarının 2006 Ocak-2018 Ocak dönemi için izlediği seyir verilmiştir.

Şekil 1: Sektör Için 2006 Ocak-2018 Ocak Dönemi Kaldıraç Oranları Seyri

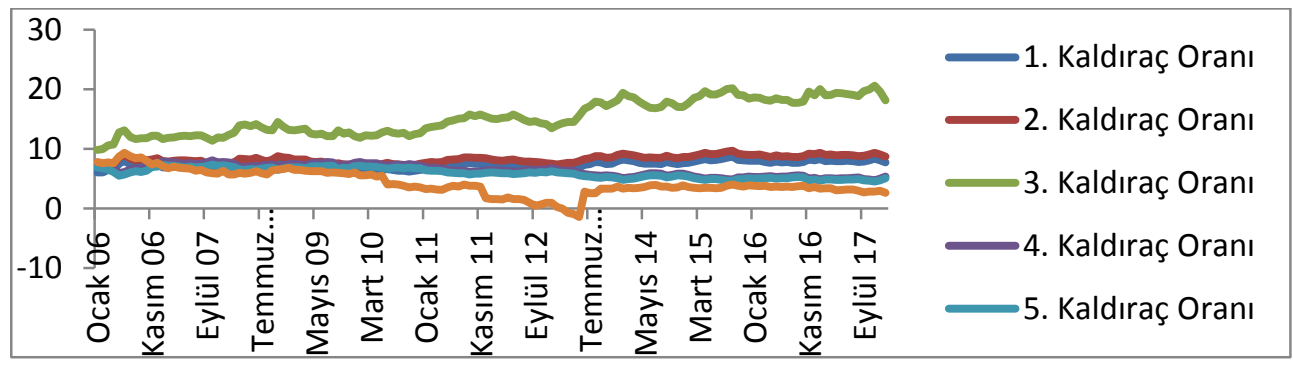

Şekil 1'e bakıldığında, 1. ve 2. Kaldıraç oranlarının uzun süreli çevrimler yaşadığı ve ortalama etrafında hareket ettiği izlenmektedir. Öte yandan, bilanço dışı işlemlerin artış göstermesinin etkisi, 3. Kaldıraç oranı üzerinde görülebilmektedir. 3. Kaldıraç oranı, inceleme dönemi içinde 
artış eğilimi sergilemekte ve daha kısa süreli çevrimler yaşamaktadır. 4. ve 5. Kaldıraç oranları ise, uzun süreli çevrim yaşamamış ve hareketlenmeden seyirlerine devam etmişlerdir. 6 . Kaldıraç oranı, kısa süreli çevrimler yaşayarak, 2009 yılı itibariyle düşmeye başlamış ve 2012 yılından sonra keskin düşüşe maruz kalmıştır. Yasal özkaynaklardaki artışla birlikte, 6. Kaldıraç oranı, 2014 yılı itibariyle, uzun süreli çevrim trendine girmiş ve bu şekilde seyrine devam etmiştir.

Zaman serileri ile çalışılan modellerde, değişkenlerin durağanlık özelliklerinin belirlenmesi önem arz etmektedir. Durağan olmayan serilerle yapılan tahminlerde, sahte regresyon problemi ortaya çıkabilmektedir. Gujarati (1995), regresyon analizinin gerçek ilişkiye işaret etmesinin, zaman serilerinin durağanlık özellikleriyle yakından ilişkili olduğunu belirtmiştir. Bu sebeple doğru model seçimi yapmak ve sahte regresyonu önlemek amacıyla, çalışmada kullanılan zaman serilerinin ilk olarak durağanlık özellikleri Geliştirilmiş Dickey-Fuller (ADF) testi ile araştırılmıştır. Tablo 4'te, Tablo 5'te, Tablo 6'da ve Tablo 7'de sektör ve banka gruplarına ait zaman serilerine ilişkin ADF birim kök testleri yer almaktadır.

Tablo 4: Sektör Zaman Serileri için ADF Birim Kök Testi

\begin{tabular}{ccc}
\hline \multirow{2}{*}{ Değişkenler } & \multicolumn{2}{c}{ Seviye Değerleri } \\
\cline { 2 - 3 } & Sabitli & Sabitli/Trendli \\
\hline 1. KOD & $-12,19(0)^{(a)}$ & $12,26(0)^{(a)}$ \\
2. KOD & $-11,75(0)^{(a)}$ & $-11,92(0)^{(a)}$ \\
4. KOD & $-5,48(1)^{(a)}$ & $-6,01(2)^{(a)}$ \\
5. KOD & $-5,54(1)^{(a)}$ & $-5,55(1)^{(a)}$ \\
6. KOD & $-5,65(1)^{(a)}$ & $-5,70(1)^{(a)}$ \\
AD & $-11,89(0)^{(a)}$ & $-11,89(0)^{(a)}$ \\
\hline
\end{tabular}

*(a) ifadesi, \%1 düzeyinde istatistiki anlamlılı̆ı ifade etmektedir. Parantez içindeki rakamlar uygun gecikme uzunlukları olup, Schwartz Bilgi Kriteri'ne (SIC) göre belirlenmiştir.

Tablo 4'te yer alan sektör zaman serileri için uygulanan ADF testi sonuçlarına göre, 1. KOD, 2. KOD, 3. KOD, 4. KOD, 5. KOD, 6. KOD, AD değişkenlerinin seviye değerlerinde durağan olmadığını ifade eden $\mathrm{H}_{0}$ hipotezinin reddedildiği, fakat değişkenlerin seviye değerlerinde durağan olduğunu belirten $\mathrm{H}_{1}$ hipotezinin reddedilemediği tespit edilmiştir.

Tablo 5: Mevduat Bankaları Zaman Serileri Için ADF Birim Kök Testi

\begin{tabular}{ccc}
\hline Değişkenler & \multicolumn{2}{c}{ Seviye Değerleri } \\
\cline { 2 - 3 } & \multicolumn{1}{c}{ Sabitli } & Sabitli/Trendli \\
\hline 2. KOD & $-11,13(0)^{(\mathrm{a})}$ & $-11,11(0)^{(\mathrm{a})}$ \\
3. KOD & $-11,12(0)^{(\mathrm{a})}$ & $-11,1(0)^{(\mathrm{a})}$ \\
4. KOD & $-11,36(0)^{(\mathrm{a})}$ & $-11,36(0)^{(\mathrm{a})}$ \\
5. KOD & $-11,17(3)^{(\mathrm{a})}$ & $-11,33(0)^{(\mathrm{a})}$ \\
6. KOD & $-11,16(0)^{(\mathrm{a})}$ & $-11,13(0)^{(\mathrm{a})}$ \\
AD & $-4,66(2)^{(\mathrm{a})}$ & $-4,65(2)^{(\mathrm{a})}$ \\
\end{tabular}

*(a) ifadesi, \%1 düzeyinde istatistiki anlamlılı̆ıı ifade etmektedir. Parantez içindeki rakamlar uygun gecikme uzunlukları olup, SIC'a göre belirlenmiştir.

Tablo 5 'te yer alan mevduat bankaları zaman serileri için gerçekleştirilen ADF birim kök testi sonuçları, 1. KOD, 2. KOD, 3. KOD, 4. KOD, 5. KOD, 6. KOD ve AD değişkenlerinin seviye değerlerinde durağan olmadığını ifade eden $\mathrm{H}_{0}$ hipotezinin reddedildiğine; fakat, değişkenlerin seviye değerlerinde durağan olduğunu belirten $\mathrm{H}_{1}$ hipotezinin reddedilemediğine işaret etmektedir. 
Tablo 6: Kalkınma ve Yatırım Bankaları Zaman Serileri Için ADF Birim Kök Testi

\begin{tabular}{ccc}
\hline Değişkenler & \multicolumn{2}{c}{ Seviye Değerleri } \\
\cline { 2 - 3 } & Sabitli & Sabitli/Trendli \\
\hline 1. KOD & $-12,34(0)^{(a)}$ & $-12,37(0)^{(a)}$ \\
2. KOD & $-11,85(0)^{(a)}$ & $-11,96(0)^{(a)}$ \\
3. KOD & $-5,53(1)^{(a)}$ & $-5,60(0)^{(a)}$ \\
4. KOD & $-5,57(1)^{(a)}$ & $-5,62(1)^{(a)}$ \\
5. KOD & $-5,66(1)^{(a)}$ & $-5,75(1)^{(a)}$ \\
6. KOD & $-7,58(1)^{(a)}$ & $-7,55(1)^{(a)}$ \\
AD & $-12,18(0)^{(a)}$ & $-12,19(0)^{(a)}$
\end{tabular}

*(a) ifadesi, \%1 düzeyinde istatistiki anlamlılığı ifade etmektedir. Parantez içindeki rakamlar uygun gecikme uzunlukları olup, SIC'a göre belirlenmiştir.

Tablo 6'da yer alan kalkınma ve yatırım bankaları zaman serileri için uygulanan ADF birim kök testi sonuçlarından, 1. KOD, 2. KOD, 3. KOD, 4. KOD, 5. KOD, 6. KOD ve AD değişkenlerinin seviye değerlerinde durağan olmadığını ifade eden $\mathrm{H}_{0}$ hipotezinin reddedildiği; fakat, değişkenlerin seviye değerlerinde durağan olduğunu belirten $\mathrm{H}_{1}$ hipotezinin reddedilemediği görülmektedir.

Tablo 7: Katılım Bankaları Zaman Serileri İçin ADF Birim Kök Testi

\begin{tabular}{|c|c|c|}
\hline \multirow[t]{2}{*}{ Değişkenler } & \multicolumn{2}{|c|}{ Seviye Değerleri } \\
\hline & Sabitli & Sabitli/Trendli \\
\hline 1. KOD & $-11,93(0)^{(a)}$ & $-12,01(0)^{(a)}$ \\
\hline 2. KOD & $-11,95(0)^{(a)}$ & $-12,12(0)^{(\mathrm{a})}$ \\
\hline 3. KOD & $-12,6(0)^{(a)}$ & $-12,61(0)^{(\mathrm{a})}$ \\
\hline 4. KOD & $-12,9(0)^{(a)}$ & $-12,89(0)^{(a)}$ \\
\hline 5. KOD & $-12,9(0)^{(a)}$ & $-12,91(0)^{(a)}$ \\
\hline 6. KOD & $-11,45(0)^{(a)}$ & $-11,41(0)^{(a)}$ \\
\hline$A D$ & $-11,57(0)^{(a)}$ & $-10,72(0)^{(a)}$ \\
\hline
\end{tabular}

*(a) ifadesi, \%1 düzeyinde istatistiki anlamlılı̆ı̆ ifade etmektedir. Parantez içindeki rakamlar uygun gecikme uzunlukları olup, SIC'a göre belirlenmiştir.

Tablo 7'de yer alan katılım bankaları zaman serileri için gerçekleştirilen ADF birim kök testi sonuçlarına göre, 1.KOD, 2. KOD, 3. KOD, 4. KOD, 5. KOD, 6. KOD ve AD değişkenlerinin seviye değerlerinde durağan olmadığını ifade eden $\mathrm{H}_{0}$ hipotezinin reddedildiği; fakat, değişkenlerin seviye değerlerinde durağan olduğunu belirten $\mathrm{H}_{1}$ hipotezinin reddedilemediği belirlenmiştir.

Çalışmada kullanılan değişkenlerin durağanlık seviyelerinin belirlenmesinin ardından, sektör ve banka grupları için ölçülen kaldıraç yapılarının döngüsellik özelliklerinin olup olmadığı EKK yöntemi ile incelenmiştir. Tablo 8' de, Tablo 9'da, Tablo 10'da ve Tablo 11'de regresyon modellerine ilişkin tahmin sonuçları yer almaktadır. 
Eskişehir Osmangazi Üniversitesi iißBF Dergisi

Tablo 8: Sektör İ̧̧in Tahmin Edilen Regresyon Modellerine iliş̧kin Sonuçlar

\begin{tabular}{|c|c|c|c|c|c|c|}
\hline & I. Model & II. Model & III. Model & IV. Model & V. Model & VI. Model \\
\hline & 1. KOD & 2.KOD & 3.KOD & 4.KOD & 5.KOD & 6.KOD \\
\hline \multirow[t]{2}{*}{$A D$} & 1,62 & 1,43 & 1,44 & $-1,18$ & $-1,08$ & 3,78 \\
\hline & {$[13,17]^{(a)}$} & {$[13,09]^{(\mathrm{a})}$} & {$[8,56]^{(a)}$} & {$[-8,12]^{(a)}$} & {$[-8,06]^{(a)}$} & {$[2]^{(\mathrm{c})}$} \\
\hline Sabit & 2,2 & 1,93 & 1,7 & $-1,39$ & $-1,28$ & 4,52 \\
\hline \multirow[t]{7}{*}{ Terim } & {$[13,17]^{(\mathrm{a})}$} & {$[13,19]^{(\mathrm{a})}$} & {$[6,25]^{(a)}$} & {$[-5,64]^{(a)}$} & {$[-5,52]^{(a)}$} & {$[1,53]$} \\
\hline & $R^{2}: 0,79$ & $R^{2}: 0,79$ & $R^{2}: 0,48$ & $R^{2}: 0,38$ & $R^{2}: 0,37$ & $R^{2}: 0,02$ \\
\hline & DW: 1,73 & DW: 1,74 & DW: 2,27 & DW: 2,11 & DW: 2,09 & DW: 2, 39 \\
\hline & F İstatistiği: & F İstatistiği: & F İstatistiği: & F İstatistiği: & F İstatistiği: & F İstatistiği: \\
\hline & $540,98^{(a)}$ & $539,86^{(a)}$ & $130,84^{(\mathrm{a})}$ & $88,19^{(a)}$ & $82,95^{(a)}$ & $2,81^{(c)}$ \\
\hline & White Testi: & White Testi: & White Testi: & White Testi: & White Testi: & White Testi: \\
\hline & $19,68^{\text {(a) }}$ & $20,32^{\text {(a) }}$ & $7,5^{(\mathrm{a})}$ & $5,05^{(\mathrm{a})}$ & $3,76^{(b)}$ & 0,28 \\
\hline
\end{tabular}

*Parantez içerisindeki (a), (b) ve (c) ifadeleri, \%1, \%5 ve \%10 önem düzeyinde istatistiki anlamlılığı ifade etmektedir. White Testi sonuçları, (VI. regresyon modeli hariç) değişen varyans probleminin olduğuna işaret etmektedir. Ayrıca, VI. regresyon modelinde otokorelason sıkıntısı mevcut olduğu tespit edilmiştir. VI. model haricinde değişen varyans problemini ve VI. model için otokorelasyon problemini gidermek için, Newey-West düzeltmesi yapılmış ve $t$ istatistikleri Newey-West'e göre düzeltilmiş halleriyle köşeli parantez içinde raporlanmıştır.

Tablo 8' de yer alan sonuçlardan görüldüğü üzere, bankacilık sektöründe yer alan tüm banka grupları için, kaldıraç döngüselliğini araştırmak amacıyla kurulan regresyon modelleri tahminlerine göre, kaldıraç oranı değişimi ve aktif değişimi arasında istatistiki olarak anlamlı ilişkiler mevcut olduğu tespit edilmiştir. Bu sonuçlar, kaldıracın döngüsel olduğuna işaret etmekte ve bankaların varlık büyümesini, kaldıraç oranlarını yükselterek yaptığına dair kanıt sunmaktadır. Nitekim, IV. ve V. modellerde AD değişkeninin katsayısının negatif ve anlamlı olması; I., II., III. ve VI. modellerde $A D$ değişkeninin pozitif yönlü katsayıya sahip olması ve istatistiki olarak anlamlılığı, inceleme döneminde bankacılık sektörünün kaldıraç yapısının döngüselliğine işaret etmektedir. Şekil 2'de sektör için kaldıraç oranı değişimleri ve aktif değişimi ilişkisini gösteren grafikler yer almaktadır.

Şekil 2: Sektör İ̧̧in Kaldıraç Oranı Değişimi ve Aktif Değişimi iliş̧kisi

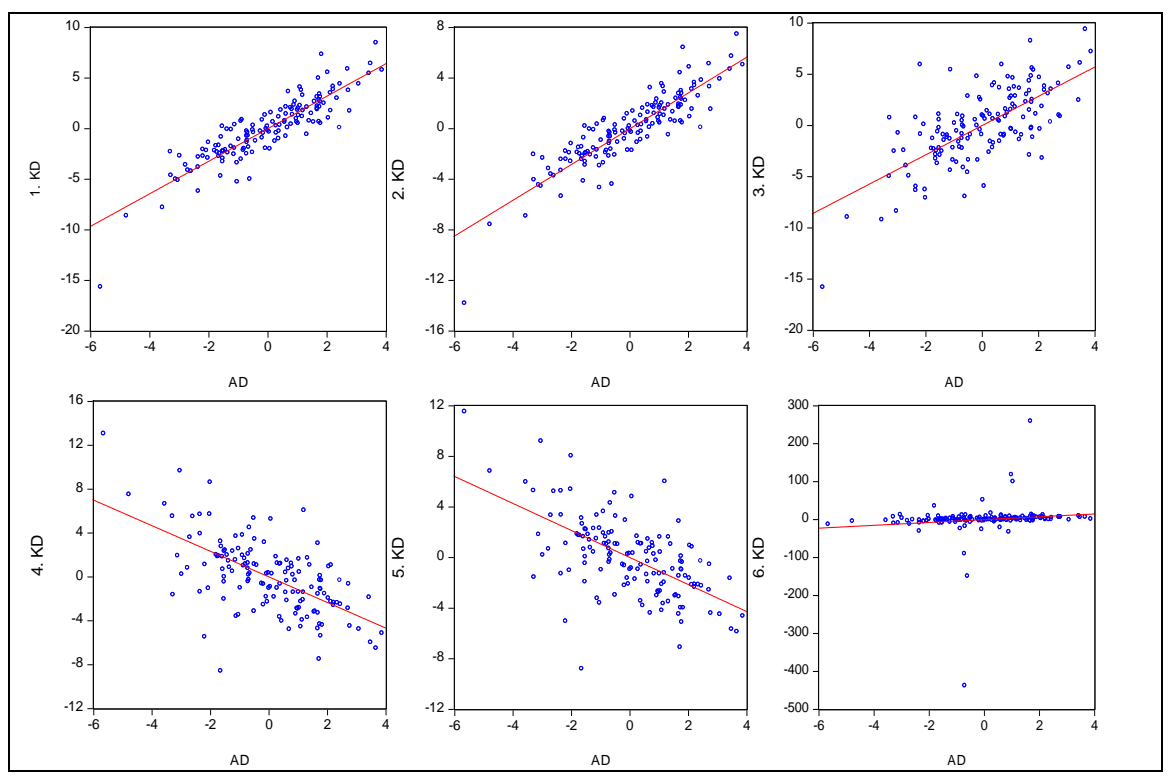


Şekil 2'den görüldügü üzere, inceleme dönemi için bankacılık sektöründe faaliyet gösteren banka gruplarının kaldıraç oranları ve aktif değişimi arasında istatistiksel olarak anlamlı ilişki olduğu belirlenmiştir.

Tablo 9: Mevduat Bankaları İçin Tahmin Edilen Regresyon Modellerine ilişskin Sonuçlar

\begin{tabular}{|c|c|c|c|c|c|c|}
\hline & I. Model & II. Model & III. Model & IV. Model & V. Model & VI. Model \\
\hline & 1. KOD & 2.KOD & 3.KOD & 4.KOD & 5.KOD & 6.KOD \\
\hline \multirow[t]{2}{*}{$A D$} & 1,66 & 1,48 & 1,45 & $-1,17$ & $-1,08$ & 0,53 \\
\hline & {$[11,86]^{(a)}$} & {$[11,75]^{(a)}$} & {$[8,03]^{(a)}$} & {$[-7,53]^{(\mathrm{a})}$} & {$[-7,52]^{(\mathrm{a})}$} & {$[0,19]$} \\
\hline \multirow[t]{7}{*}{ Sabit Terim } & 2,26 & 2 & 1,66 & $-1,34$ & $-1,25$ & $-5,77$ \\
\hline & {$[12,45]^{(a)}$} & {$[12,42]^{(a)}$} & {$[6,09]^{(a)}$} & {$[-5,47]^{(\mathrm{a})}$} & {$[-5,37]^{(\mathrm{a})}$} & {$[-0,92]$} \\
\hline & $R^{2}: 0,76$ & $R^{2}: 0,76$ & $R^{2}: 0,47$ & $R^{2}: 0,36$ & $R^{2}: 0,35$ & $R^{2}: 0,00$ \\
\hline & DW: 1,74 & DW: 1,74 & DW: 2,31 & DW: 2,14 & DW: 2,12 & DW: 1,40 \\
\hline & F İstatistiği: & F İstatistiği: & F İstatistiği: & F İstatistiği: & F İstatistiği: & F İstatistiği: \\
\hline & $459,01^{(\mathrm{a})}$ & $457,02^{(a)}$ & $124,62^{(\mathrm{a})}$ & $81,79^{(a)}$ & $76,94^{(a)}$ & 0,04 \\
\hline & $\begin{array}{l}\text { White Testi: } \\
20.24^{\text {(a) }}\end{array}$ & White Testi: & White Testi: & $\begin{array}{l}\text { White Testi: } \\
67^{\text {(a) }}\end{array}$ & $\begin{array}{l}\text { White Testi: } \\
5.07^{\text {(a) }}\end{array}$ & White Testi: \\
\hline
\end{tabular}

*Parantez içerisindeki (a) ifadesi, \%1 ve \%5 önem düzeyinde istatistiki anlamlılığı ifade etmektedir. White Testi sonuçları, değişen varyans probleminin olduğuna işaret etmektedir. Değişen varyans problemini gidermek için, Newey-West düzeltmesi yapılmış ve t istatistikleri Newey-West'e göre düzeltilmiş halleriyle köşeli parantez içinde raporlanmıştır.

Tablo 9'da yer alan mevduat bankaları için kaldıraç döngüselliğinin araştırıldığı regresyon modelleri tahminlerine göre, aktif değişimi ve kaldıraç oranları değişimi arasındaki istatistiki olarak anlamlı ilişkilerin bulunması sebebiyle, kaldıraç yapısının döngüsel özellikler taşıdığı belirlenmiştir. I., II. III. regresyon modellerinde AD değişkeni katsayısı pozitif yönlü olup, istatistiksel olarak anlamlılık taşımaktadır. Yine IV. ve V. modellerde AD değişkenin katsayısı negatif yönlü ve istatistiksel olarak anlamlıdır. Bu bulgular, mevduat bankaları için kaldıracın döngüsel olduğunu, yani varlık büyümesinin kaldıraç oranı artışını da beraberinde getirdiğine işaret etmektedir.

Şekil 3: Mevduat Bankaları İ̧̧in Kaldıraç Oranı Değişimi ve Aktif Değişimi Iliş̧skisi

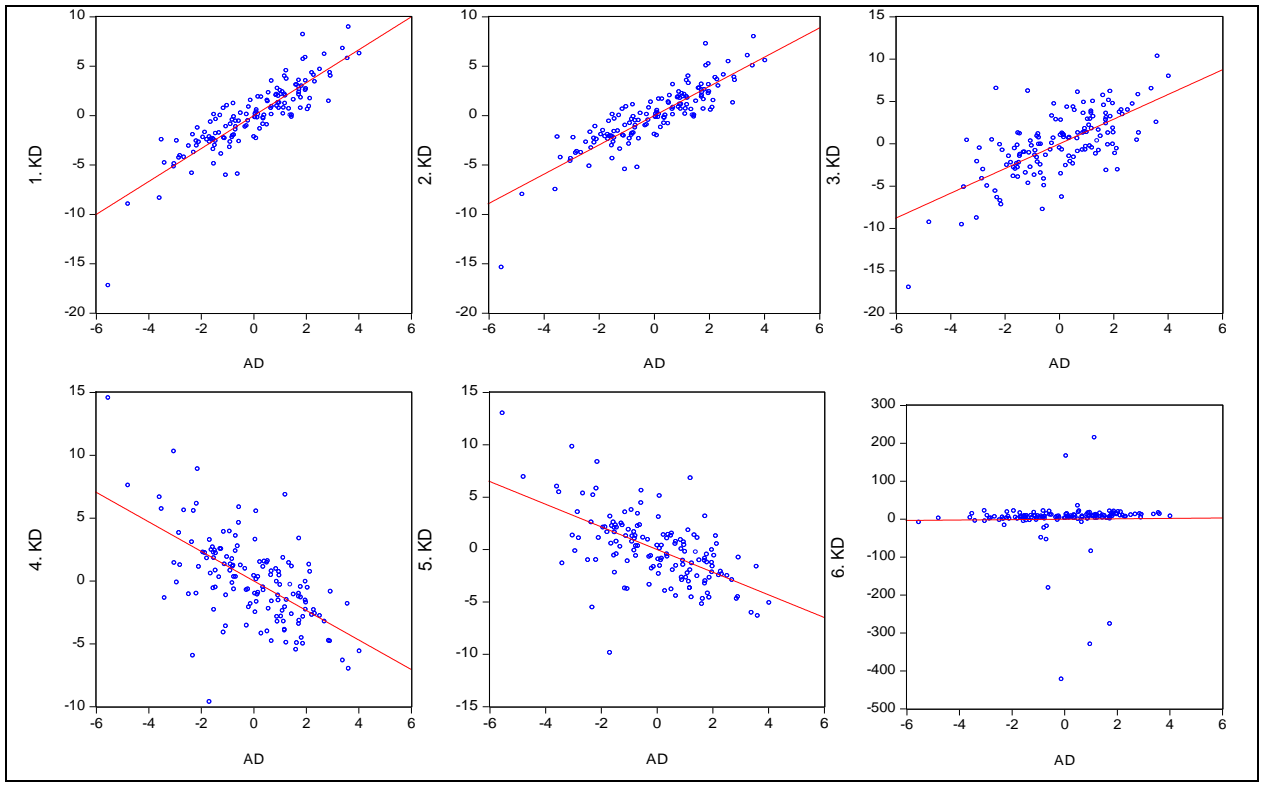


Şekil 3'te yer alan grafikler, mevduat bankaları için kaldıraç yapısının döngüsel olduğuna dair kanıt sunmaktadır ve 1., 2., 3., 4. ve 5. KOD ile AD değişkeni arasında istatistiki olarak anlamlı ilişkiler olduğu görülmektedir.

Tablo 10. Kalkınma ve Yatırım Bankaları Için Tahmin Edilen Regresyon Modellerine Iliş̧kin Sonuçlar

\begin{tabular}{|c|c|c|c|c|c|c|}
\hline & I. Model & II. Model & III. Model & IV. Model & V. Model & VI. Model \\
\hline & 1. KOD & 2.KOD & 3.KOD & 4.KOD & 5.KOD & 6.KOD \\
\hline \multirow[t]{2}{*}{$A D$} & 1,61 & 1,02 & 1,14 & $-1,14$ & $-0,87$ & 0,98 \\
\hline & {$[21,08]^{(a)}$} & {$[24,65]^{(a)}$} & {$[6,8]^{(\mathrm{a})}$} & {$[-6,7]^{(a)}$} & {$[-7]^{(a)}$} & {$[3,09]^{(b)}$} \\
\hline Sabit & 1,87 & 1,12 & 1,14 & $-0,91$ & $-0,68$ & 1,77 \\
\hline \multirow[t]{6}{*}{ Terim } & {$[8,9]^{(a)}$} & {$[9,84]^{(\mathrm{a})}$} & {$[2,41]^{(b)}$} & {$[-1,94]^{(b)}$} & {$[-1,99]^{(b)}$} & {$[1,93]^{(b)}$} \\
\hline & $R^{2}: 0,76$ & $R^{2}: 0,81$ & $R^{2}: 0,24$ & $R^{2}: 0,24$ & $R^{2}: 0,26$ & $R^{2}: 0,07$ \\
\hline & DW: 2,17 & DW: 2,2 & DW: 1,68 & DW: 1,64 & DW: 1,66 & DW: 1,93 \\
\hline & F İstatistiği: & F İstatistiği: & F İstatistiği: & F İstatistiği: & F İstatistiği: & F İstatistiği: \\
\hline & $443,98^{(a)}$ & $607,46^{(a)}$ & $46,22^{(a)}$ & $44,86^{(a)}$ & $49,05^{(a)}$ & $10,15^{(\mathrm{a})}$ \\
\hline & $\begin{array}{l}\text { White Testi: } \\
0.66\end{array}$ & $\begin{array}{l}\text { White Testi: } \\
0.44\end{array}$ & $\begin{array}{l}\text { White Testi: } \\
0,34\end{array}$ & White Testi: & $\begin{array}{l}\text { White Testi: } \\
0.65\end{array}$ & $\begin{array}{l}\text { White Testi: } \\
5.43^{(\text {b) }}\end{array}$ \\
\hline
\end{tabular}

*Parantez içerisindeki (a) ve (b) ifadeleri, \%1 ve \%5 önem düzeyinde istatistiki anlamlılığı ifade etmektedir. VI. regresyon modeli için, White Testi sonuçları, değişen varyans probleminin olduğunu göstermektedir. Değişen varyans problemini gidermek için, Newey-West düzeltmesi yapılmış ve t istatistikleri Newey-West'e göre düzeltilmiş halleriyle köşeli parantez içinde raporlanmıştır.

Tablo 10'da yer alan kalkınma ve yatırım bankaları için kaldıraç döngüselliğinin araştırıldığı regresyon modellerinde, kaldıraç oranları ve aktif değişimleri arasında istatistiki olarak anlamlı ilişkiler, kaldıracın döngüsel olduğu sonucuna işaret etmektedir. Öyleki; I., II. III. ve VI. modellerde aktif değişimi değişkeninin katsayısının pozitif yönlü olması; IV. V. modellerde yer alan aktif değişimi değişkeninin katsayısının negatif yönlü olması kaldıraç döngüselliğinin mevcut olduğuna dair kanıt sunmaktadır. Bu bulgulara göre, kalkınma ve yatırım bankaları kaldıraç yapılarının döngüsellik özelliğine sahip olduğu belirlenmiştir.

Şekil 4: Kalkınma ve Yatırım Bankaları İ̧̧in Kaldıraç Oranı Değiş̧imi ve Aktif Değişimi iliş̧kisi

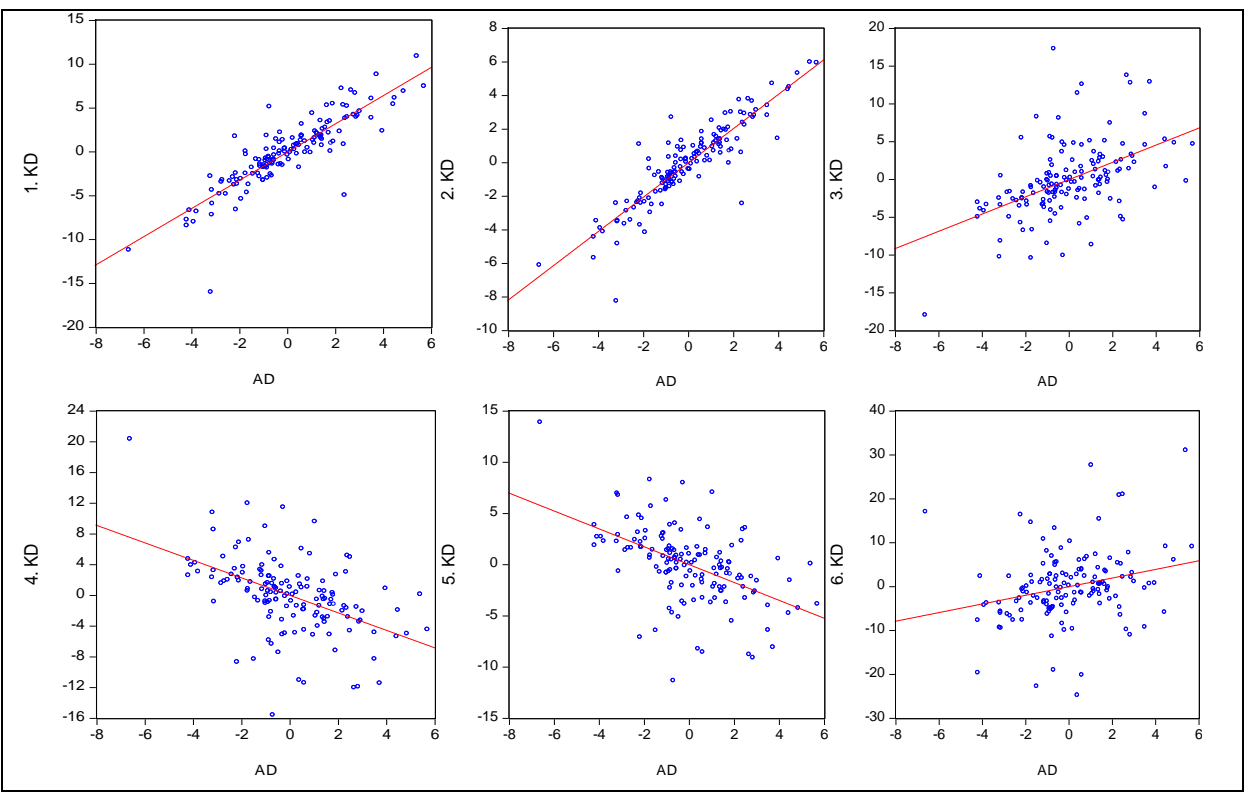


Şekil 4'ten görüldüğü üzere, kalkınma ve yatırım bankaları için aktif ve kaldıraç oranları değişimi arasındaki istatistiki olarak anlamlı ilişkiler mevcuttur.

Tablo 11: Katılım Bankaları İçin Tahmin Edilen Regresyon Modellerine iliş̧in Sonuçlar

\begin{tabular}{|c|c|c|c|c|c|c|}
\hline & I. Model & II. Model & III. Model & IV. Model & V. Model & VI. Model \\
\hline & 1. KOD & 2.KOD & $3 . \mathrm{KOD}$ & $4 . \mathrm{KOD}$ & $5 . \mathrm{KOD}$ & $6 . \mathrm{KOD}$ \\
\hline \multirow[t]{2}{*}{$A D$} & 0,68 & 0,61 & 0,59 & $-0,63$ & $-0,59$ & $-0,68$ \\
\hline & {$[2,9]^{(a)}$} & {$[2,69]^{(\mathrm{a})}$} & {$[2,84]^{(\mathrm{a})}$} & {$[-2,82]^{(a)}$} & {$[-2,80]^{(a)}$} & {$[-0,83]$} \\
\hline Sabit & 1,22 & 1,07 & 1,19 & $-1,14$ & $-1,05$ & $-1,97$ \\
\hline \multirow[t]{6}{*}{ Terim } & {$[2,68]^{(\mathrm{a})}$} & {$[2,92]^{(\mathrm{a})}$} & {$[3,36]^{(a)}$} & {$[-3,06]^{(a)}$} & {$[-3,05]^{(a)}$} & {$[-0,84]$} \\
\hline & $R^{2}: 0,19$ & $R^{2}: 0,19$ & $R^{2}: 0,12$ & $R^{2}: 0,13$ & $R^{2}: 0,13$ & $R^{2}: 0,00$ \\
\hline & DW: 1,81 & DW: 1,81 & DW: 2,12 & DW: 2,16 & DW: 2,16 & DW: 1,93 \\
\hline & F İstatistiği: & F İstatistiği: & F İstatistiği: & F İstatistiği: & F İstatistiği: & F İstatistiği: \\
\hline & $33,25^{(a)}$ & $33,64^{(\mathrm{a})}$ & $19,20^{(a)}$ & $21,3^{(a)}$ & $21,18^{(a)}$ & 0,4 \\
\hline & $\begin{array}{c}\text { White Testi: } \\
33,92^{(a)}\end{array}$ & $\begin{array}{c}\text { White Testi: } \\
35,31^{\text {(a) }}\end{array}$ & $\begin{array}{c}\text { White Testi: } \\
16,96^{\text {(a) }}\end{array}$ & $\begin{array}{c}\text { White Testi: } \\
25,32^{(a)}\end{array}$ & $\begin{array}{c}\text { White Testi: } \\
25,46^{\text {(a) }}\end{array}$ & $\begin{array}{c}\text { White Testi: } \\
\quad 0,28\end{array}$ \\
\hline
\end{tabular}

*Parantez içerisindeki (a) ve (b) ifadeleri, \%1 ve \%5 önem düzeyinde istatistiki anlamlılı̆̆ ifade etmektedir. White testi sonuçları, değişen varyans probleminin olduğunu göstermektedir. Değişen varyans problemini gidermek için, NeweyWest düzeltmesi yapılmış ve t istatistikleri Newey-West'e göre düzeltilmiş halleriyle köşeli parantez içinde raporlanmıştir.

Tablo 11'de raporlanan katılım bankaları için aktif ve kaldıraç oranları değişimi arasındaki regresyon analizi sonuçlarına göre, I. II. ve III. modellerde aktif değişimi değiş̧keninin katsayısının pozitif yönlü ve istatistiki olarak anlamlı; IV. ve V. modellerde yer alan aktif değişimi değişkeninin katsayısının negatif yönlü ve istatistiki olarak anlamlı olması, kaldıraç döngüselliğine işaret etmektedir. Bu durumda, katılım bankaları kaldıraç yapısının döngüsel özellik taşıdığı Tablo 11 'den görülmektedir.

Şekil 5: Katılım Bankaları Iç̧in Kaldıraç Oranı Değişimi ve Aktif Değişsimi iliş̧kisi

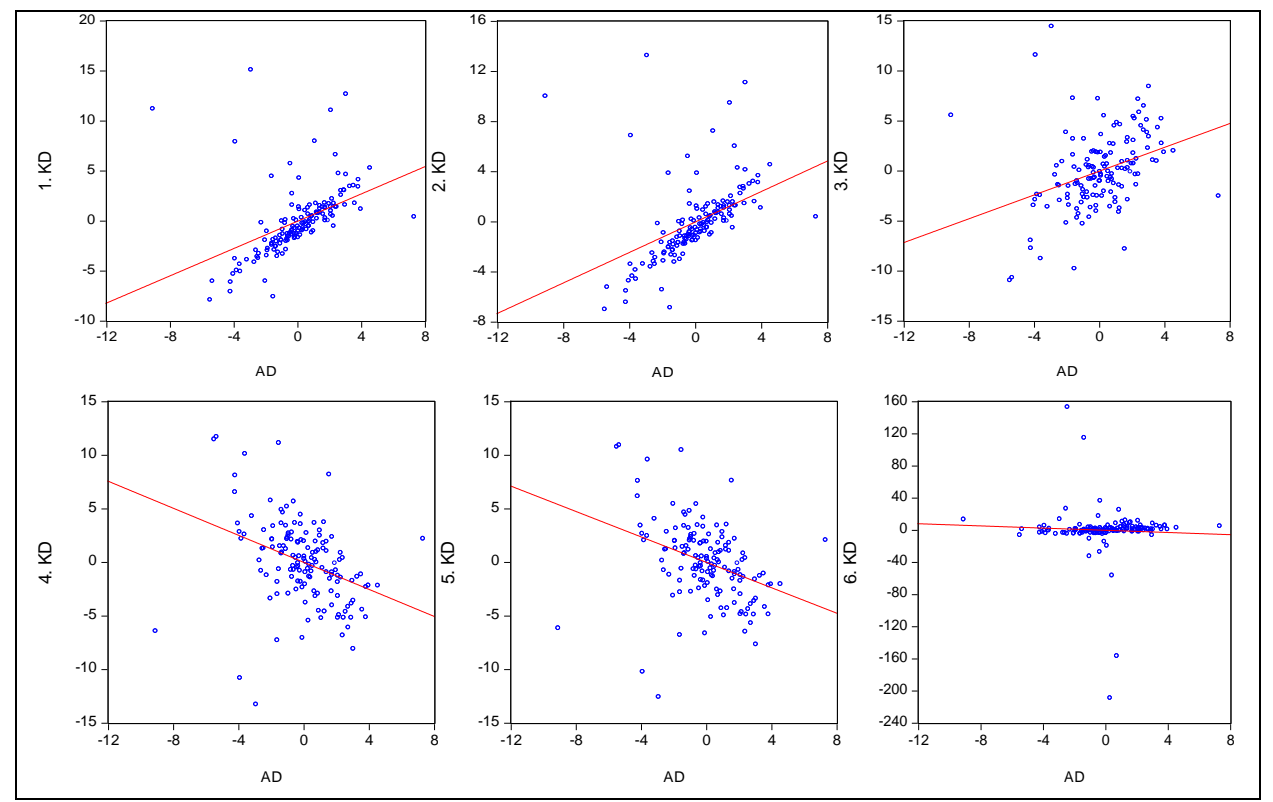

Şekil 5'te yer alan grafiklere göre, katılım bankaları için inceleme döneminde kaldıraç oranları ve aktif değişimi arasında istatistiki olarak anlamlı bir ilişki olduğu (VI. model hariç) tespit edilmiştir. 


\section{Sonuç}

2008 yılında ABD'de başlayan ve daha sonra diğer ülkelere yayılan Mortgage krizi öncesi, kaldıraç oranlarının yükselmesi, varlık büyümesine sağladığı katkı açısından önemsenmemiştir. Fakat, 2008 yılı Mortgage krizi sonrası, kaldıraç oranlarının döngüsellik özelliği taşımasının finansal hızlandırıı mekanizması olmasından ileri geldiği ve bu aşırı hızlanmanın banka iflaslarına sebep olduğu ortaya çıkmıştır. Uluslararası düzenleyici kuruluşlar, Basel II'nin kaldıraç oranlarının döngüsellik taşıması riskine ilişkin eksikliklerine karşılık Basel III'ü geliştirmişlerdir. Basell III ile kaldıraç oranlarının hızlandırıcı mekanizma olma özelliğine kontrol edici düzenlemeler getirilmiştir. Petersen vd. (2013), bu kontrol mekanizmasının yeknesaklıktan kaynaklı riskleri barındırmakta olduğunu ve döngüselliğin neden olduğu risklerin ortaya çıkarılmasında bazı eksiklikleri içerdiğini belirtmişlerdir. D'Hulster (2009) ise, kaldıraç oranının makro ve mikro riskleri azaltıcı bir araç olarak kullanılabileceğini savunmakta; fakat, tek başına finansal riskleri azaltıcı bir mekanizma olması durumunu eleştirmektedir. Bu sebeple, D’Hulster (2009), kaldıraç oranlarının Basel türü sermaye yeterlilik rasyoları ile kullanılmasının yüksek borçlanmadan ileri gelen risk birikimini azaltacağı görüşünü savunmuştur.

Bu çalışmada amaç, 2006 Ocak-2018 Ocak zaman aralığında faaliyet gösteren mevduat, katılım ile kalkınma ve yatırım bankalarının sektör ve grup olarak kaldıraç döngüselliklerini araştırmaktır. Bu kapsamda hem sektör hem de banka grupları için aktif ve kaldıraç oranı değişimi zaman serileri arasındaki ilişkiyi ölçmek için EKK yöntemi ile regresyon analizi uygulanmıştır. Regresyon analizlerine ilişkin tahmin sonuçları, hem sektör için hem de mevduat, katılım ile kalkınma ve yatırım bankaları için kaldıracın döngüsel olduğuna işaret etmektedir. Çalışma kapsamında elde edilen bu bulgular ise, Çalışkan (2011) ve Binici ve Köksal (2012) tarafından Türk bankacılık sistemi için gerçekleştirilen çalışmaların bulgularıyla paralellik arz etmektedir.

Kaldıraç oranı ve aktif büyüklüğü arasındaki ilişkinin döngüsel olması, finansal çevrimleri hızlandırabilmekte ve bu durumda kaldıraç oranına finansal hızlandırıcı mekanizma olma özelliği kazandırabilmektedir. Bankacılık sektöründe faaliyet gösteren bankalar, varlık büyümesi durumunda, daha fazla kaynak sağlayarak kaldıraç oranlarını yükseltmektedirler. Varlık fiyatlarının düşmesi durumunda ise, bankalar, kaldıraç yapısını değiştirerek, kaldıraç oranlarını düşürme eğilimine girmektedirler. Böylelikle, bankacılık sektörünün büyüme gösterdiği dönemler, kredi çevrimlerinin genişlediği dönemlere paralel olmaktadır. Bu şekilde kaldıraç yapısı, makro riskleri azaltıcı bir araç şeklinde kullanılabilmekte ve kredi çevrimlerinin etkisini yumuşatılabilmektedir. Çalışmada Türk bankacılık sektöründe faaliyet gösteren bankalar için bu çalışmada gerçekleştirilen ampirik testlerden hareketle, finansal genişleme dönemlerinde, politika yapıcı kurumlar, standartların getirmiş olduğu yasal zorunluluklar olmasına rağmen, döngüsel karşıtı bir mekanizma kullanarak bankaların, varlık ve kredi büyümesini hafifletici önlemler almasını sağlayabilirler. Böylelikle, döngüsel karşıtı bir politika ile, kredi ve finansal çevrimlerinin etkisi hafifletilerek, döngüsellik kaynaklı varılı büyümesi şişkinliği giderilebilir. Dolayısıyla, kaldıracın döngüsellliğinin ve finansal çevrimleri tetiklediği dönemlerde, bu çalışma için döngüsel karşıtı bir kaldıraç oranı belirlenmesi politika önermesidir.

Bu çalışmada kaldıraç döngüselliği, sektör ve banka grupları açısından incelenmiştir. İlerleyen dönemlerde yapılacak olan çalışmalarda, banka gruplarının kamu ve özel veya yerli ve yabancı şeklinde ayrıştırılarak, kaldıraç yapısının döngüselliğinin incelenmesi ile elde edilecek bulguların bankacılık sektörü açısından faydalı olabileceği düşünülmektedir. Ayrıca, çalışma kapsamında elde edilen bulguların politika yapıcılara, finans yöneticilerine ve finansal analistlere yol gösterici özellik taşıması beklenmektedir. 


\section{Kaynaklar}

Adrian, Tobias; Shin, Hyung Song (2008), “Liquidity and Leverage”, International Monetary Fund Financial Cycles, Liquidity, and Securization Conference.

Adrian, Tobias; Shin, Hyung Song (2010), 'Liquidity and Leverage", Journal of Financial Intermadiation, Vol. 19, No. 3: 418-437.

Amel-Zadeh, Amir; Barth, Mary E.; Landsman, Wayner. (2015), "The Contribution of Bank Regulation and Fair Value Accounting to Procyclical Leverage", Rock Center for Corporate Governance at Stanford University Working Paper, 147.

Athanasoglou, Panayiotis; Daniilidis, Ioannis; Delis, Mathos (2014), "Bank Procyclicality and Output: Issues and Policies", Journal of Economics and Business, Vol. 72: 58-83.

Avcı, Emin; Çatak, Çiydem (2016), “Banka Sermaye Yapısının Belirleyicileri ve Kaldıraç Döngüselliği: Türkiye İçin Ampirik Bir Analiz", Marmara Business Review, C. 1, S. 2: 41-57.

Baglioni, Aangelo; Beccalli, Elena; Boitani, Aandrea; Monticini, Aandrea (2013), "Is The Leverage of European Banks Procyclical?", Empirical Economics, Vol. 45: 1251-1266.

Bernanke, Ben S.; Gertler, Mark (1989), “Agency Costs, Net Worth and Business Fluctuations", American Economic Review, Vol. 79: 14-31.

Binici, Mahir; Köksal, Binici (2012), “Is The Leverage of Turkish Banks Procyclical?”, Central Bank Review, Vol. 12, No. 2: 11-24.

Bruno, Valentina; Shin, Hyun S. (2015), "Cross-Border Banking and Global Liquidity", The Review of Economic Studies, Vol. 82, S. 2: 535-564.

Çalışkan, Ahmet (2011), "Leverage Behavior of Turkish Banks: How Did They Escape the Global Crisis?", iktisat İsletme ve Finans Dergisi, C. 26, S. 307: 75-104.

D’Hulster, Katia (2009), "The Leverage Ratio", The World Bank Group, Financial and Private Sector Development Vice Presidecey, Note Number 11.

Damar, H. Evren (2010), "Leverage, Balance Sheet Size and Wholesale Funding", Bank of Canada Working Paper, 39,144 .

Gropp, Reint; Heider, Florian (2010), "The Determinants of Bank Capital Structure", Review of Finance, Vol. 14: 587622.

Gujarati, Damodar N. (1995), Basic Econometrics, İstanbul: Literatür Yayıncılık.

Kalemli-Özcan, Şebnem; Sorensen Bent; Yeşiltaş, Sevcan (2011), "Leverage Across Firms, Banks, and Countries", NBER Working Papers, 17354, 1-55.

Keynes, Jhon M. (1936), The General Theory of Employment, Interest and Money, McMillan: London.

Kiyotaki, Nobuhiro; Moore, Jhon (1997), “'Credit Cycles”, Journal of Political Economy, Vol. 105: 211-248.

Kyounghoon, Park (2016), “Heterogeneous Procyclicality of Bank Leverage: Empiricial Evidence of U.S. Bank Holding Companies", SSNR Electronic Journal.

Laux, Christian; Rauter, Thomas (2017), “Procyclicality of U.S. Bank Leverage”, Journal of Accounting Research, Vol. 55, No. 2: 237-273.

Minsky, Hyman P. (1982), Can It Happen Again? Essays on Instability and Finance, New York: M. E. Sharpelnc., R. Monk.

Petersen, Mark A.; Maruping, Jacob B.; Mukuddem-Petersen, Janine; Hlatshwayo, Lungile N. P. (2013), “Basel Perspective on Bank Leverage", Applied Financial Economics, Vol. 23, No. 17: 1361-1369.

Terzioğlu, Mustafa; Demir, Yusuf (2015), “Leverage Procyclical of Turkish Deposit Banks”, Journal of Economics Finance and Accounting, C. 2, S. 4: 546-557.

Wu, Yiyong; Hu, Ridong (2017), "A Study of The Leverage Pro-cyclical Behavior and Asymmetry of Commercial Banks in China", Revista de Cercetare Şilnterventie Sociala, Vol. 59: 136-152. 
Eskişehir Osmangazi Üniversitesi IißBF Dergisi 